\title{
A process economic assessment of hydrocarbon biofuels production using chemoautotrophic organisms
}

\author{
Nymul E. Khan ${ }^{a}$, John A. Myers ${ }^{a, b}$, Amalie L. Tuerk ${ }^{a, c}$, Wayne R. Curtis ${ }^{a *}$ \\ aDepartment of Chemical Engineering, The Pennsylvania State University, University \\ Park, PA 16802, USA. \\ ${ }^{\mathrm{b}}$ Current address: Motiva Enterprises, Houston, TX 77210 \\ ${ }^{c}$ Current address: Department of Chemical and Biomolecular Engineering, University of \\ Delaware, Newark, DE 19716, USA \\ * Corresponding author. \\ E-mail address: wrc2@psu.edu (W.R. Curtis)
}

\begin{abstract}
Economic analysis of an ARPA-e Electrofuels ${ }^{1}$ process is presented, utilizing metabolically engineered Rhodobacter capsulatus or Ralstonia eutropha to produce the $\mathrm{C}_{30+}$ hydrocarbon fuel, botryococcene, from hydrogen, carbon dioxide, and oxygen. The analysis is based on an Aspen plus® bioreactor model taking into account experimentally determined Rba. capsulatus and Rls. eutrohpa growth and maintenance requirements, reactor residence time, correlations for gas-liquid mass-transfer coefficient, gas composition, and specific cellular fuel productivity. Based on reactor simulation results encompassing technically relevant parameter ranges, the capital and operating costs of the process were estimated for $5000 \mathrm{bbl-fuel/day} \mathrm{plant} \mathrm{and} \mathrm{used} \mathrm{to} \mathrm{predict} \mathrm{fuel} \mathrm{cost.} \mathrm{Under} \mathrm{the}$ assumptions used in this analysis and crude oil prices, the Levelized Cost of Electricity (LCOE) required for economic feasibility must be less than $2 \varnothing / \mathrm{kWh}$. While not feasible under current market prices and costs, this work identifies key variables impacting process cost and discusses potential alternative paths toward economic feasibility.
\end{abstract}

\footnotetext{
${ }^{1} \mathrm{http} / / /$ arpa-e.energy.gov/?q=arpa-e-programs/electrofuels
} 


\section{Keywords}

Electrofuels; botryococcene; carbon fixation; hydrocarbon; Rhodobacter capsulatus;

Ralstonia eutropha; autotrophic metabolism; bioreactor modeling; process economics;

large scale $k_{L} a$ review.

${ }^{1} \mathrm{http}: / /$ arpa-e.energy.gov/?q=arpa-e-programs/electrofuels 2 


\section{List of symbols and abbreviations}

\begin{tabular}{|c|c|}
\hline$a, b, c, d$ & Stoichiometric coefficients in cell growth equation \\
\hline$C_{i}$ & $\begin{array}{l}\text { Liquid phase concentration of } i \text {-th gas component, } \\
\mathrm{mol} \cdot \mathrm{L}^{-1}\end{array}$ \\
\hline$C_{\text {fuel }}$ & Concentration of fuel in the bioreactor, $\mathrm{mol} \cdot \mathrm{L}^{-1}$ \\
\hline$\frac{d C_{i}}{d t}$ & $\begin{array}{l}\text { Rate of consumption of } i \text {-th gas component, } \mathrm{mol} \cdot \mathrm{L}^{-} \\
{ }^{1} \cdot \mathrm{hr}^{-1}\end{array}$ \\
\hline$X$ & Cell density, gDW $\cdot \mathrm{L}^{-1}$ \\
\hline $\begin{array}{l}{\left[\frac{d C_{i}}{d t}\right]_{\text {growth }},\left[\frac{d C_{i}}{d t}\right]_{\text {fuel }}} \\
{\left[\frac{d C_{i}}{d t}\right]_{\text {maint }},\left[\frac{d C_{i}}{d t}\right]_{\text {total }}}\end{array}$ & $\begin{array}{l}\text { Rate of substrate utilization for growth, fuel } \\
\text { synthesis, maintenance requirements and total } \\
\text { respectively, mol. } \mathrm{L}^{-1} \cdot \mathrm{hr}^{-1}\end{array}$ \\
\hline$V$ & Reactor volume, $\mathrm{L}$ \\
\hline$F$ & Rate of liquid feed into reactor, $\mathrm{L} \cdot \mathrm{hr}^{-1}$ \\
\hline$\tau$ & Residence time through reactor, $\mathrm{V} / \mathrm{F}, \mathrm{hr}^{-1}$ \\
\hline$\varepsilon$ & Cell recycle efficiency \\
\hline$\mu, \mu_{\max }$ & $\begin{array}{l}\text { Specific growth rate and maximum specific growth } \\
\text { rate of cells, } \mathrm{hr}^{-1}\end{array}$ \\
\hline$R_{\text {fuel }}$ & Specific fuel productivity, $\mathrm{g}$-fuel $\cdot \mathrm{gDW}^{-1} \cdot \mathrm{hr}^{-1}$ \\
\hline $\bar{P}_{f}$ & Volumetric fuel productivity, $\mathrm{g}$-fuel $\cdot \mathrm{L}^{-1} \cdot \mathrm{hr}^{-1}$ \\
\hline$r_{\text {growth }}$ & Rate of growth of cells, $\mathrm{gDW} \cdot \mathrm{L}^{-1} \cdot \mathrm{hr}^{-1}$ \\
\hline$Y_{H_{2}}^{T}$ & True growth yield of cells on $\mathrm{H}_{2}, \mathrm{gDW} \cdot \mathrm{mol}^{-1}$ \\
\hline
\end{tabular}




\begin{tabular}{|c|c|}
\hline$m_{\mathrm{H}_{2}}, m_{\mathrm{O}_{2}}$ & $\begin{array}{l}\text { Maintenance coefficient of cells on } \mathrm{H}_{2} \text { and } \mathrm{O}_{2} \\
\text { respectively } \mathrm{mol} \cdot \mathrm{gDW}^{-1} \cdot \mathrm{hr}^{-1}\end{array}$ \\
\hline$Y_{f / H_{2}}$ & Yield of fuel on $\mathrm{H}_{2}$, g-fuel. $\left(\text { mol- } \mathrm{H}_{2}\right)^{-1}$ \\
\hline$y_{i}$ & Gas phase mole fraction of $i$-th component \\
\hline$P_{t o t}$ & Total pressure, atm \\
\hline$H_{i}$ & $\begin{array}{l}\text { Henry's law coefficient of } i \text {-th gas component, } \\
\mathrm{atm} \cdot \mathrm{L} \cdot \mathrm{mol}^{-1}\end{array}$ \\
\hline$\overline{D_{i}}$ & Diffusion coefficient of $i$-th gas component, $\mathrm{m}^{2} \cdot \mathrm{s}^{-1}$ \\
\hline$G T R_{i}$ & Gas transfer rate of $i$-th gas component, $\mathrm{mol} \cdot \mathrm{L}^{-1} \cdot \mathrm{hr}^{-1}$ \\
\hline$k_{L} a_{i}$ & $\begin{array}{l}\text { Gas-liquid mass transfer coefficient of the } i \text {-th } \\
\text { component, } \mathrm{hr}^{-1}\end{array}$ \\
\hline gDW & Grams dry weight \\
\hline $\mathrm{bbl}$ & US fluid barrel \\
\hline LCOE & Levelized Cost of Electricity \\
\hline EROI & Energy Return on Investment \\
\hline IGCC & Integrated Gasification Combined Cycle \\
\hline NGCC & Natural Gas Combined Cycle \\
\hline $\mathrm{PC}$ & Pulverized Coal \\
\hline
\end{tabular}




\section{Introduction}

Fossil fuels have provided a readily accessible and energy-dense fuel source to pave the way for science and technology advancements. However, fossil fuel reservoirs, which accumulated over millions of years, are a finite resource that must be replaced with more sustainable alternative liquid fuels. Corn ethanol, the most widely produced biofuel in the United States, made up less than 5\% of transportation fuels in 2011 (www.eia.gov). Furthermore, there is ongoing controversy related to corn-ethanol contributing to higher food prices. Additional constraints on alternative fuel technologies include valuation of carbon credits and assurance of economic and political energy security. These competing issues demand the development of transformative technologies for producing renewable liquid fuels able to meet our society's growing energy needs.

The Electrofuels initiative, administered by the United States Department of Energy's Advanced Research Projects Agency - Energy (ARPA-E), aimed to develop liquid biofuels that avoid the issues encountered in the current generation of biofuels: (1) the reliance of biomass-derived technologies on the inefficient process of photosynthesis, (2) the relatively energy- and resourceintensive nature of agronomic processes, and (3) the occupation of large areas of arable land for feedstock production (http://arpa-e.energy.gov/?q=arpa-e-programs/electrofuels). To address these issues, the Electrofuels initiative funded research efforts that sought to develop biological processes that would convert distributed, off-grid, renewable electricity into alternative liquid fuels. The logic of this approach rests in its ability to provide a reliable energy source for the transportation sector by storing transiently-available electrical energy in a chemical bond (Figure 1A). In addition, the Electrofuels approach is synergistic with advances in photovoltaic cells. 
Under the Electrofuels initiative, a range of approaches to this challenge were funded (summary found in (Tuerk, 2011)). The concept for our approach is depicted schematically in Figure 1A, and involves collecting and transporting electrons to a centralized bioreactor for biological capture of the reducing power in the chemical bonds of a hydrocarbon fuel. This proceeds by: (1) the capture of solar energy into electrical energy via photovoltaic cells (with demonstrated laboratory efficiencies upwards of $40 \%$, a seven-fold improvement on photosynthesis), (2) the use of the generated electricity to split water into molecular hydrogen $\left(\mathrm{H}_{2}\right)$ and oxygen $\left(\mathrm{O}_{2}\right)$, and (3) feeding these gases, along with carbon dioxide $\left(\mathrm{CO}_{2}\right)$ emitted from point sources such as a biomass or coal-fired power plant, to a microbial bioprocessing platform. Our proposed microbial bioprocessing platform leverages a chemolithoautotrophic microorganism naturally able to utilize these gases as growth substrates, and genetically modified to produce a triterpene hydrocarbon fuel molecule native to the alga Botryococcus braunii. The details and rationale of these choices are discussed below.

This exercise of using process economic analyses to research priorities is an important aspect of the ARPA-E program. An initial analysis of the economic feasibility of the microbial process, based on microbial energetic theory, can be found in an extensive thesis (Tuerk, 2011). A preliminary process economic model can also be found in a co-author's honors thesis (Myers, 2013). In this work, we expand upon these previous analyses by constructing a more detailed bioreactor model in Aspen Plus ${ }^{\circledR}$ (described in section 2.2). Furthermore, we examined specific scenarios based on reactor residence time $(\tau)$, specific fuel productivity $\left(R_{f u e l}\right)$ and gas-liquid mass transfer coefficient $\left(k_{L} a\right)$ to predict their effect on the overall process volumetric fuel productivity $\left(\bar{P}_{f}\right)$ and fuel cost ( $\$ /$ bbl-fuel). The ultimate goal of this analysis was to identify 
limiting parameters for the process and ranges of these variables needed to achieve economic feasibility.

\subsection{Rationale for Selection of the Microbial Bioprocessing Platform}

Biological approaches for producing alternative fuels are benefitting from advances in molecular biology. These developments have increased the range of fuel molecule targets that can be synthesized by living organisms (Farmer and Liao, 2001; Kim et al., 2006), as well as expanded the selection of alternative hosts for production through the development of new genetic engineering tools (Steinbrenner and Sandmann, 2006). However, current work most frequently uses $E$. coli or yeast as the microbial host with carbohydrate (i.e. fixed-carbon) based substrates. Our approach to the Electrofuels initiative leverages developments in alternative hosts capable of autotrophic growth on $\mathrm{H}_{2}$ as well as developments in fuel targets.

\subsubsection{Microbial Host Selection}

For this economic analysis, we decided to include two different chemolithoautotrophs (microbes growing on $\mathrm{H}_{2}, \mathrm{O}_{2}$ and $\mathrm{CO}_{2}$ ) based on specific differences in their physiology, metabolism and energetic yields. Initially motivated by the production of the industrially relevant biopolymer poly-hydroxy butyrate (PHB), the chemoautotrophic growth mode was developed as an alternative approach to bioprocessing using Ralstonia eutropha (Tanaka et al., 1995). Highdensity growth (40 - 90 gDW/L) of Rls. eutropha on gaseous substrates was achieved in high gas-liquid-mass-transfer bioreactors with controlled addition of inorganic nutrients, demonstrating the technical feasibility of such a process. We are also investigating the use of Rhodobacter capsulatus, a purple non-sulfur facultative phototroph, as a candidate because of its capability of diverse metabolic modes (including autotrophic), ability to utilize a range of growth substrates, and innate high level production of carotenoids (Hunter et al., 2009) indicating that 
pathways for isoprenoid biosynthesis are already present in this organism. We have recently achieved significant milestones, including production of $>100 \mathrm{mg} / \mathrm{L}$ botryococcene, by genetically engineering Rba. capsulatus (Khan et al., 2013), validating its potential as an alternative host for isoprene based fuels and molecules. As will be discussed later, Rba. capsulatus is less efficient in utilizing $\mathrm{H}_{2}$ for growth, but has lower maintenance requirements than Rls. eutropha, differences which provide economic tradeoffs in an Electrofuels process. The range of yield and maintenance parameters between Rba. capsulatus and Rls. eutropha is likely representative of most chemoautotrophs and we were interested in quantifying how these contrasting energetic needs affect the overall economics of the process.

\subsubsection{Hydrocarbon Fuel Molecule Selection}

One of the largest barriers faced by alternative energy technologies is poor economics relative to fossil fuels. Having been the most widely developed biofuel to date, ethanol has achieved the most success competing economically with gasoline. However, ethanol's relative competitiveness results in part from governmental subsidies and mandates that ensure lower cost of ethanol feedstocks and higher selling prices (Solomon et al., 2007). Estimates of the Energy Return on Investment (EROI) of corn-derived ethanol currently range from a mere 0.7 to 1.65 , while those estimated for cellulosic ethanol range from 4.40 to 6.61 (de Castro et al., 2014; Hammerschlag, 2006).

We have chosen the hydrocarbon botryococcene as the product of the Electrofuels process as a means of addressing issue of energy-intensive industrial processing, which is a major drawback to ethanol production. In choosing this fuel molecule target, the project leveraged our experience in working with the alga Botryococcus braunii (Khatri et al., 2014) and the associated discovery of the enzymes responsible for the synthesis of $\mathrm{C}_{30}$ squalene and botryococcene (Okada et al., 
2004). $C_{30+}$ triterpenes include methylated botryococcenes and squalenes, and are produced by $B$. braunii race B, a colonial green algae that accumulates these hydrocarbon oils up to 30 percent of its dry weight composition (Metzger and Largeau, 2005). Ancestors of this alga have been implicated in producing up to 1.4 percent of the total hydrocarbon in maar-type oil shales based on the unique carbon footprint of $\mathrm{C}_{34}$ botryococcene oil (Derenne et al., 1997). They have properties similar to crude oil (Hillen et al., 1982), a higher energy density than ethanol (38.1 vs. $23.5 \mathrm{~kJ} / \mathrm{L}$ ) (Tuerk, 2011) and can be easily separated from an aqueous phase by decantation (Khatri et al., 2014). Given these advantages, it was anticipated that the production of botryococcenes could yield higher EROI than ethanol.

\section{Materials and methods: model development}

\subsection{Proposed electrofuels production process}

The process flow diagram of the proposed Electrofuels production process is depicted in Figure 1B. Production of the $\mathrm{C}_{30+}$ hydrocarbon fuel by the host organism occurs in the bioreactor, which is fed the gaseous substrates $\mathrm{H}_{2}, \mathrm{O}_{2}$ and $\mathrm{CO}_{2}$. The relative amount of these gases fed is equal to the ratio that supports growth and fuel production by the bacteria. The determination of this stoichiometric ratio is discussed in further detail under the section 2.2.3. Other nutrients required for cell growth, such as salts and vitamins, are fed to the bioreactor via a liquid stream. The bioreactor is operated continuously and the bioreactor effluent contains biomass, botryococcene fuel product, and spent culture medium. An underlying assumption critical to this process configuration is that the botryococcene fuel is excreted and deposited as a hydrophobic layer on top of the culture, which can be separated by decantation (oil-water separator). The decanted hydrocarbon layer then flows from the oil-water separator to a fuel filtration system where the 
residual aqueous phase is removed, and the fuel molecules can then exit the process as the crude hydrocarbon product. We did not include subsequent processing, such as hydrocracking, within the scope of this economic analysis, since the point of comparison is crude oil, which would require similar downstream processing (Hillen et al., 1982).

The aqueous phase that exits the oil-water separator flows to a cell clarifier. This concentrates the biomass phase before returning a portion of the biomass to the bioreactor, and the remaining biomass to sludge processing to avoid accumulation of dead cells and cellular waste (perfusion mode operation). The spent media passes through a waste treatment process to remove cellular debris and waste material, and is recycled as fresh medium after supplementing with salts and other nutrients.

\subsection{Bioreactor modeling}

The biological processes taking place in the bioreactor (cell growth, maintenance and fuel molecule synthesis) determine the rate of substrate consumption $\left(\mathrm{H}_{2}, \mathrm{CO}_{2}, \mathrm{O}_{2}\right)$, and therefore the gas-liquid mass-transfer $\left(k_{L} a\right)$ requirements, which are the most critical components of the bioreactor operating cost. The bioreactor volumetric fuel productivity (dependent on the specific fuel productivity, residence time and $k_{L} a$ ) and the scale of the process (bbl-fuel/day) determine the required size of all associated process equipment, and thus the capital and fixed costs. The capital investment at that plant size can then be amortized at a nominal internal rate of return and combined with the operating costs to arrive at an estimated cost for crude fuel production (\$/bblfuel). A detailed model of the bioreactor processes associated with hydrocarbon fuel production, which includes cell growth and maintenance, fuel synthesis, and gas transport, is therefore a critical prerequisite to accurately estimating the capital and operating costs. 
In aerobic chemolithoautotrophic metabolism (referred to as 'autotrophic' metabolism from here on), electrons are transferred from $\mathrm{H}_{2}$ to $\mathrm{O}_{2}$ through a series of steps which generate the energy needed for various cellular processes, including $\mathrm{CO}_{2}$ fixation for growth and fuel synthesis. Thermodynamic models (McCarty, 2007; Mccarty, 1971; Tuerk, 2011) can be used to calculate these requirements. The microbial substrate requirements ultimately reduce to stoichiometric equations that can be incorporated in a bioreactor model. To integrate the bioreactor model with the full model of the Electrofuels process, we used Aspen plus® software. We selected Aspen plus ${ }^{\circledR}$ as it can solve complicated material and energy balance equations with rigorous physical property determinations, and we selected the RCSTR reactor model to incorporate the microbial energetic equations described below in sections 2.2.1 through 2.2.4.

\subsubsection{Substrate requirement for cell growth}

Figure 2A depicts the conceptual framework for modeling cell growth and maintenance processes. In this context, growth processes refer to the use of energy and carbon substrates for the production of new cellular biomass, whereas cellular maintenance is the use of energy substrates for non-growth processes such as motility, ion pumping, futile cycling etc. (Pirt, 1965; van Bodegom, 2007). For autotrophic metabolism, the process of cell growth (excluding energy demands for maintenance) can be represented by a stoichiometric relationship, the 'growth equation' as shown below in Equation 1.

$\mathrm{CO}_{2}+a \mathrm{H}_{2}+\mathrm{bNH}_{4}^{+}+\mathrm{cO}_{2} \rightarrow \operatorname{Cell}\left[\mathrm{CN}_{b} \mathrm{H}_{2 a+3 b-2 d} \mathrm{O}_{(2+2 c-d)}\right]+\mathrm{dH}_{2} \mathrm{O}+\mathrm{bH}^{+}$

In this relationship, the inorganic carbon source $\left(\mathrm{CO}_{2}\right)$, electron donor $\left(\mathrm{H}_{2}\right)$, electron acceptor $\left(\mathrm{O}_{2}\right)$, and nitrogen source (ammonium, $\mathrm{NH}_{4}^{+}$) are consumed, resulting in the formation of cell biomass, water $\left(\mathrm{H}_{2} \mathrm{O}\right)$, and hydrogen ions $\left(\mathrm{H}^{+}\right)$. Consequently, the rate of consumption of each of 
the gases due to growth processes $\left(\left[\frac{d C_{i}}{d t}\right]_{\text {growth }}\right.$, where $i$ represents $\left.\mathrm{H}_{2}, \mathrm{CO}_{2}, \mathrm{or}_{2}\right)$ is related to the rate of cell growth $\left(\frac{d[X]}{d t}\right)$ by Equation 2,

$\mathbf{r}_{\text {growth }}=\frac{d[X]}{d t}=\frac{1}{a}\left[\frac{d C_{\mathrm{H}_{2}}}{d t}\right]_{\text {growth }}=\frac{1}{c}\left[\frac{d C_{\mathrm{O}_{2}}}{d t}\right]_{\text {growth }}=\left[\frac{d C_{\mathrm{Co}_{2}}}{d t}\right]_{\text {growth }}$

The indices for the elements $\mathrm{N}, \mathrm{H}$ and $\mathrm{O}$ in the cell biomass term of Equation $1[b, 2 a+3 b-$ $2 d$ and $2+2 c-d$, respectively] were obtained from literature reports of the empirical elemental formula for cell biomass for each Rba. capsulatus and Rls. eutropha (Hoekema et al., 2006; Ishizaki and Tanaka, 1990), resulting in three of the four equations needed to calculate the four coefficients $a, b, c$ and $d$. The fourth equation needed to complete the set is from the true growth yield (substrate requirement for growth that could occur in the absence of cellular maintenance requirements) of the bacteria on the energy substrate $\mathrm{H}_{2}\left(Y_{\mathrm{H}_{2}}^{T}\right)$ and is related to the coefficient $a$ by Equation 3,

$Y_{H_{2}}^{T}=\frac{F W_{\text {cell }}}{a}$

where $F W_{\text {cell }}$ is the formula weight of one 'mole' of cell according to the empirical formula for cell biomass. Because $Y_{H_{2}}^{T}$ is the quantity of $\mathrm{H}_{2}$ needed for growth-only processes (and does not include energy requirements for maintenance), this parameter can be obtained through the use of microbial energetic models or experimental measurements (Pirt, 1965).

\subsubsection{Substrate requirement for cellular maintenance}

Additional consumption of $\mathrm{H}_{2}$ and $\mathrm{O}_{2}$ occurs in order to generate energy for cellular maintenance. Because cellular maintenance requirements are defined as independent of energy requirements for growth, the simplest way to conceive of these requirements is to consider them 
on a per-time, per mass of cell basis, and thus the maintenance coefficients $\left(m_{\mathrm{H}_{2}}\right.$ and $\left.m_{\mathrm{O}_{2}}\right)$ are a measure of the rate of substrate required to satisfy the maintenance needs of one unit mass of cells. The rate of consumption of $\mathrm{H}_{2}$ and $\mathrm{O}_{2}$ due to cellular maintenance is therefore proportional to the total biomass concentration in the reactor, $\mathrm{X}$, as shown in Equation 4.

$m_{H_{2}} X=\left[\frac{d C_{H_{2}}}{d t}\right]_{\text {maint }}=\frac{1}{2} m_{O_{2}} X$

$m_{\mathrm{O}_{2}}$ is related to $m_{\mathrm{H}_{2}}$ by a factor of two because of the stoichiometry of water formation, which is the reaction for energy generation in autotrophic metabolism since electrons from $\mathrm{H}_{2}$ are transferred to $\mathrm{O}_{2}$. We initially presented values of $Y_{\mathrm{H}_{2}}^{T}$ and $m_{H_{2}}$ based on literature reports and used them in conjunction with microbial energetic theory to predict net growth and fuel yields under variety of conditions (Tuerk, 2011). To confirm these estimates towards improving the accuracy of this economic analysis, we have recently measured the values of $Y_{\mathrm{H}_{2}}^{T}$ and $m_{\mathrm{H}_{2}}$ under identical conditions for both Rba. capsulatus and Rls. eutropha using an adaptation of the traditional methods using continuous chemostat cultures under autotrophic conditions (Pirt, 1965).

\subsubsection{Substrate requirement for fuel synthesis}

To incorporate botryococcene fuel synthesis into the bioreactor model, we first defined a parameter, $R_{f u e l}$, the specific fuel productivity. The rate of fuel synthesis is therefore given by Equation 5.

$\left[\frac{d C_{f u e l}}{d t}\right]_{\text {fuel }}=R_{f u e l} X$

The botryococcene fuel molecule, $\mathrm{C}_{34} \mathrm{H}_{58}$, is energetically expensive to synthesize. Therefore, additional $\mathrm{H}_{2}$ and $\mathrm{O}_{2}$ must be consumed to provide energy for fuel synthesis, beyond the 
requirements for cell growth. We designate the parameter $f$ to account for the additional $\mathrm{H}_{2}$ which must be oxidized in order to provide this energy; this is above and beyond the hydrogen incorporated into the botryococcene molecules themselves. The overall fuel synthesis reaction is summarized in Equation 6. This treatment is analogous to cell growth and maintenance described in sections 2.2.1 and 2.2.2.

$34 \mathrm{CO}_{2}+(29+f) \mathrm{H}_{2}+\frac{f}{2} \mathrm{O}_{2} \rightarrow \mathrm{C}_{34} \mathrm{H}_{58}+\mathrm{fH}_{2} \mathrm{O}$

The minimum energetic requirement for botryococcene synthesis from $\mathrm{CO}_{2}$ via the CalvinBenson-Bassham (CBB) and mevalonic acid (MVA) pathways can be calculated by summing the total Gibbs energy required for generating the cofactors (mainly ATP, NAD(P)H and NADH) in the metabolic steps. A simplified version of the relevant metabolic pathways is shown in Figure 2B. The cofactor requirement for going from mevalonate to botryococcene has been previously elucidated by (Okada et al., 2004). The total Gibbs energy required for synthesizing one mol of botryococcene from $\mathrm{CO}_{2}$ was converted to the amount of $\mathrm{H}_{2}$ ( $f$ in Equation 6 ) that must be oxidized to provide this energy. The rate of consumption of $\mathrm{H}_{2}, \mathrm{O}_{2}$ and $\mathrm{CO}_{2}$ for fuel synthesis can then be calculated through Equation 7,

$R_{f u e l} X=\frac{1}{29+f}\left[\frac{d C_{H_{2}}}{d t}\right]_{f u e l}=\frac{2}{f}\left[\frac{d C_{o_{2}}}{d t}\right]_{f u e l}=\frac{1}{34}\left[\frac{d C_{C O_{2}}}{d t}\right]_{f u e l}$

The fuel mass yield on $\mathrm{H}_{2}\left(Y_{f / H_{2}}\right)$ is defined as the quantity $\frac{F W_{f u e l}}{29+f}$, where $F W_{f u e l}$ is the formula weight of botryococcene.

\subsubsection{Mass transfer limitations for gas transport and optimization}

The total rate of consumption of each of the gases is the sum of the contributions from cell growth, cellular maintenance, and fuel production (Equation 8), 
$\left[\frac{d C_{i}}{d t}\right]_{\text {total }}=\left[\frac{d C_{i}}{d t}\right]_{\text {growth }}+\left[\frac{d C_{i}}{d t}\right]_{\text {maint }}+\left[\frac{d C_{i}}{d t}\right]_{\text {fuel }}$

Based on this premise, the volumetric productivity of botryococcene is ultimately constrained by the mass transfer rate of the limiting gas substrate into liquid. At steady state conditions in the bioreactor, where liquid-phase gas concentrations are constant, the uptake rate of the $i$-th gas substrate by the organism $\left(\left[\frac{d C_{i}}{d t}\right]_{\text {total }}\right)$ is equal to the gas transfer rate of this gas component $\left(G T R_{i}\right)$. For gaseous component $i$, these rates can be calculated from the gas phase fractional composition $\left(y_{i}\right)$, the total gas pressure $\left(P_{t o t}\right)$, the gas-liquid mass transfer coefficient $\left(k_{L} a_{i},\right)$, Henry's law coefficient $\left(H_{i}\right)$ and the liquid phase concentration $\left(C_{i}\right)$, as shown in Equation 9:

$\left[\frac{d C_{i}}{d t}\right]_{\text {total }}=G T R_{i}=k_{L} a_{i}\left(\frac{y_{i} P_{t o t}}{H_{i}}-C_{i}\right)$

Thus, this equation illustrates that the $G T R_{i}$, and therefore the total possible gas uptake by the organisms, are limited by the $k_{L} a_{i}$ that is possible in a particular reactor type.

To simultaneously satisfy the organism's $\mathrm{H}_{2}, \mathrm{O}_{2}$, and $\mathrm{CO}_{2}$ demands, there is only one set of $y_{i}$ at which all the gases are transported at a stoichiometrically balanced rate. At any other gas composition, only the limiting component will transport at the maximum rate $\left(\left[C_{i}\right]=0\right)$, while the other components are transported at a sub-maximal rate $\left(\left[C_{i}\right]>0\right)$. Therefore, the bioreactor must be operated at the gas composition that results in maximum transport rate of each of the gases to achieve the highest volumetric productivity. In practice, this could be achieved by controlling the gas phase composition via feedback control loops. In our simulations, we used the optimization functionality in Aspen plus ${ }^{\circledR}$ to converge on the optimal gas composition. Because the bioreactor $k_{L} a_{i}$ also affects the $G T R_{i}$, as described above, we constrained the optimization by limiting $k_{L} a_{O_{2}}$ to values correlated for bioreactor configurations. Fixing $k_{L} a_{O_{2}}$ then fixes $k_{L} a_{H_{2}}$ 
and $k_{L} a_{\mathrm{CO}_{2}}$, as these are related to $k_{L} a_{O_{2}}$ by the diffusion coefficient correction to mass transfer (Equation 10),

$k_{L} a_{i}=k_{L} a_{o_{2}}\left(\frac{D_{i}}{D_{o_{2}}}\right)^{2 / 3}$

An inter-conversion based on diffusion coefficient to $2 / 3$ power is used. This is because correlations in literature are typically reported for $k_{L} a_{O_{2}}$ as a function of operating conditions (rpm, gas rate etc.) and mass transfer coefficients have an inherent dependence on gas diffusion in the associated boundary layer, which needed to be captured in the analysis.

\section{Results and discussion}

Continuous operation provides for the high productivity required for fuel production. Extracellular botryococcene accumulation allows for the recycle of biomass for a higher operating concentration and higher process volumetric productivity. Since achieving economic feasibility is anticipated to be challenging, these operational enhancements are assumed as baseline requirements.

\subsection{Sensitivity analysis: effect of reactor residence time $(\tau)$}

In a perfusion bioreactor, the residence time through the reactor system $(\tau=\mathrm{V} / \mathrm{F})$ and cell retention efficiency $(\varepsilon)$ determine the required cell proliferation rate $(\mu)$ and operational cell concentration $(X)$. These subsequently affect the rate at which fuel will be produced for a given specific fuel productivity $\left(R_{f u e l}\right)$. The economics of this process are highly dependent on the volumetric fuel productivity $\left(\bar{P}_{f}\right.$; this sets the required reactor size and therefore the capital cost) 
and the fuel yield on $\mathrm{H}_{2},\left(Y_{f / H_{2}}\right.$; the major operating cost). Therefore, we performed an initial set of simulations to evaluate the effect of reactor residence time on these two variables (Figure 3). The steady state cell density in the reactor is also presented to assist in interpretation (Figure 3C) and to establish the operational cell concentration that must be achievable using the host organism. For these simulations experimentally determined values for microbial energetic parameters were used (unpublished data): true growth yield $\left(Y_{H_{2}}^{T}\right)$ and maintenance coefficient $\left(m_{\mathrm{H}_{2}}\right)$ of both Rba. capsulatus $\left(2.66 \mathrm{gDW} / \mathrm{mol}-\mathrm{H}_{2}\right.$ and $2.01 \times 10^{-3} \mathrm{~mol}-\mathrm{H}_{2} / \mathrm{gDW} . \mathrm{hr}$, respectively) and Rls. eutropha (7.68 gDW/mol- $\mathrm{H}_{2}$ and $6.8 \times 10^{-3}$ mol- $\mathrm{H}_{2} / \mathrm{gDW} . \mathrm{hr}$, respectively). Figure 3 presents the results for the chosen process variables: $k_{L} a_{O_{2}}=330 / \mathrm{hr}, R_{f u e l}=0.5 \mathrm{~g}$-fuel/gDW.hr and $\varepsilon=95 \%$.

The results indicate that $\mathrm{X}, \bar{P}_{f}$ and $Y_{f / H_{2}}$ all increase with residence time, asymptotically approaching maximum values. This behavior results from the opposing effects of $\mathrm{X}$ and $\tau$ : in a continuous flow bioreactor, $\frac{1}{\tau}=$ growth rate of the bacteria $(\mu)=\frac{1}{X} \frac{d X}{d t}\left(\right.$ given $\frac{1}{\tau}<\mu_{\max }$ ). Therefore, as $\tau$ increases, specific growth rate decreases. Since the volumetric rate of substrate availability is fixed by gas mass transfer $\left(k_{L} a\right)$, the reduction in specific growth rate and reduced gas consumption per cell permit an increased steady state cell concentration with an associated greater fuel production per unit volume. Based on the assumption that metabolism can be directed to produce fuel instead of cell mass results in operating at lower growth rates. At lower growth rates less of the available $\mathrm{H}_{2}$ must be partitioned to cell growth, enabling more of the $\mathrm{H}_{2}$ to be used towards synthesizing fuel, and enabling a higher $Y_{f / H_{2}}$. This is reflected in Figure $3 \mathrm{C}$. The preceding discussion also explains the important observation that at higher residence times (and lower growth rates) the organism with lower maintenance requirement (Rba. capsulatus, in 
this case) is predicted to perform better despite its less efficient utilization of $\mathrm{H}_{2}$ for growth. This is because at a lower growth rate, a smaller fraction of the available energy substrate is used for maintenance, leaving more $\mathrm{H}_{2}$ available for fuel synthesis. The assumption that mass transfer limitations are the dominant constraint on bioreactor operation is central to this argument. Because it is desirable to operate at higher fuel yield and volumetric productivity, $Y_{\mathrm{H}_{2}}^{T}$ and $m_{\mathrm{H}_{2}}$ of Rba. capsulatus and $\tau=15 \mathrm{hr}$ were chosen for further simulations.

\subsection{Sensitivity analysis: effect of specific productivity $\left(R_{f u e l}\right)$}

Specific fuel productivity is an intrinsic biological property of a genetically engineered production strain, and affects the volumetric productivity as well as the fuel yield on $\mathrm{H}_{2}$. The range of specific fuel productivities examined in this analysis spanned from 0.1 to $2 \mathrm{~g}$ fuel/gDW.hr (Figure 4A). This is a wide range covering conservative to very optimistic specific productivity targets. As a reference, the ethanol specific productivities of E. coli growing on various fixed-carbon substrates reported in the literature range from about 0.3 to $0.8 \mathrm{~g} \cdot \mathrm{gDW}^{-1} \cdot \mathrm{hr}^{-}$

${ }^{1}$ (estimated from Ohta et al, 1991; Hildebrand et al, 2013). The resulting fuel yields on $\mathrm{H}_{2}$ were converted to electricity required $(\mathrm{kWh} / \mathrm{bbl}$ fuel), based on an average electrolytic efficiency of $80 \%$ for $\mathrm{H}_{2}$ generation (Myers, 2013). This is the major component of the operating cost of the process. In the range of low specific productivities, the electricity requirement for $\mathrm{H}_{2}$ generation initially decreases sharply as specific productivity increases. This is attributed to the fact that when specific productivity is low, the majority of the energy is expended in the growth of cells rather than ending up in the fuel molecule, so small improvements in specific productivity give large electricity cost savings. However, the electricity requirement remains essentially unchanged above specific productivities of $1 \mathrm{~g}$-fuel $\cdot \mathrm{gDW}^{-1} \cdot \mathrm{hr}^{-1}$. This asymptotic minimum is the 
sum of the energy fixed in the fuel molecule and the minimum loss that is associated with cell growth and maintenance.

Specific productivity is the target associated with genetic engineering and development of the host organism. Obviously, higher is better, but the more important question is: at what range of specific productivity will the process achieve economic viability? Initial efforts to introduce the botryococcene synthesis pathway via metabolic engineering approaches have successfully produced the botryococcene molecule (Khan et al., 2013); however, the observed production levels are more than an order of magnitude lower than the low-range values used in this simulation. For the current, experimentally observed productivity levels, it was calculated that the electricity cost would be about 175 times that of the $0.1 \mathrm{~g}$-fuel. $\mathrm{gDW}^{-1} \cdot \mathrm{hr}^{-1}$ specific productivity case. The genetic engineering efforts are well justified because a small increase in specific productivity (which is possible at the early stages of development) translate to large savings in electricity cost. However, after a significant productivity has been attained, and electricity requirements level off, other aspects of the process become increasingly important for achieving economic feasibility. For our subsequent analysis, the moderately optimistic level of $0.5 \mathrm{~g}$-fuel $\cdot \mathrm{gDW}^{-1} \cdot \mathrm{hr}^{-1}$ was used.

\subsection{Sensitivity analysis: effect of gas-liquid mass transfer coefficient ( $\left.k_{L} a\right)$}

The mass transfer rate affects the volumetric productivity and therefore determines the reactor volume required at a given production capacity, as discussed in section 2.2.3. Increasing $k_{L} a$ comes at the expense of increased operating costs for mass transfer, but this facilitates a decrease in the capital cost due to a reduction in the required reactor volume. Figure $4 \mathrm{~B}$ shows the decrease in reactor volume and increase in energy cost $\left(\mathrm{kWh} / \mathrm{bbl}\right.$-fuel) for an increase in $k_{L} a$ from 330 to $1000 \mathrm{hr}^{-1}$ for a range of bioreactor configurations. To serve as a guide in determining 
relevant reactor costs and realistic $k_{L} a$ values, the ranges of $k_{L} a$ used in Figure $4 \mathrm{~B}$ and the associated power-per-unit-volume $(\mathrm{P} / \mathrm{V})$ are based on values for various gas-liquid contacting reactors reported in the literature. The compilation is presented in Figure 5. In performing the literature review, we focused on systems that can be operated at the large scale required for this process. The key is to choose a bioreactor where high mass transfer can be sustained at relatively low power levels. In this respect, trickle-bed reactors were found to perform the best at commercial scales. While microbubble reactors have similar performance, they have only been demonstrated at the laboratory scale. We have therefore used trickle-bed reactor costs in our final analysis.

Comparing the energy costs for $k_{L} a$ enhancements in Figure $4 \mathrm{~B}$ to the costs of energy for $\mathrm{H}_{2}$ production in Figure 4A, energy required for mass transfer is only 1.5 to $4.5 \%$ of the minimum energy required for $\mathrm{H}_{2}$ generation $(\sim 4000 \mathrm{kWh} / \mathrm{bbl}$-fuel). This result emphasizes the dominance of $\mathrm{H}_{2}$ generation requirements in overall energy requirements. Optimizing $k_{L} a$, therefore, will only become important in the later stages of plant design when more accurate equipment costs are available. Therefore in determining the total capital and operating cost of the process, we selected a $k_{L} a$ of $1000 \mathrm{hr}^{-1}$.

\subsection{Process economic analysis of capital and operating costs}

The preceding analysis, based on specific productivity and mass-transfer requirements, helps define the realistic range to conduct a more detailed analysis of capital and operating costs. Table 1 shows the values selected for parameters used in this section of the work, all of which are based on the calculations described above. The scaled-up process design is based on a daily production rate of 5,000 barrels of oil per day $(795,000 \mathrm{~L} / \mathrm{d})$. As a reference point, in 2012 the 
largest ethanol production facility in the United States had a nameplate capacity of slightly over 27,000 bpd, while the average facility produced around 4,500 bpd (Nebraska, 2014).

A capital cost analysis provides insight into the overall economics of a production platform by (1) identifying the relative costs of the various components and (2) quantifying the relative magnitude of the capital cost in relation to the fixed and operating costs. The capital costs of the production equipment were determined using Aspen plus® software, except for electrolysis cells, whose capital costs were calculated based on literature data (Saur, 2008). We did not include the capital costs of the renewable electricity generation component in our analysis because this is accounted for through the use of Levelized Cost of Electricity (LCOE) for a particular electricity source; therefore, these costs are incorporated into the cost of $\mathrm{H}_{2}$. This choice was made because reliable and up-to-date studies on the costs of various renewable electricity technologies already exist (IRENA, 2012; REN21, 2013). The results of the capital cost analysis are presented in Figure 6A; as can be seen, the costs of the process components varied over a range of three orders of magnitude. We grouped the equipment into categories of lower and higher cost, and note that the capital cost of photovoltaics included in $\mathrm{H}_{2}$ generation costs corresponds to the highest capital expense.

The capital cost of the platform (excluding $\mathrm{H}_{2}$ production) is $\$ 24.44 / \mathrm{bbl}$-fuel, assuming an aftertax rate of return of $15 \%$ (Figure $6 \mathrm{~B}$ ). The fixed cost component was much smaller than the capital cost component at $\$ 8.81 / \mathrm{bbl}$-fuel. The operating cost of the process is highly dependent on the cost of electricity and the LCOE of electricity is quite variable for the various types of renewable energy technologies. However, the cost of nutrient feed-water, wastewater, cooling water, and $\mathrm{CO}_{2}$ are relatively insensitive to electricity cost, and amount to $\sim \$ 18.9 / \mathrm{bbl}$-fuel. Although we expected $\mathrm{CO}_{2}$ cost to be minimal due to it being a waste product, surprisingly, this 
cost was found to be the most significant cost after electricity. In this analysis we assume that $\mathrm{CO}_{2}$ from a power plant or a similar point source will be purified, compressed, and transported to this facility for use. The magnitude of this cost varies substantially with the types of point source, carbon capture technology employed, and the means of transport. The average of the cost of capture and compression of $\mathrm{CO}_{2}$ for IGCC, NGCC and PC power plants is reported to be $\$ 31 /$ tonne- $\mathrm{CO}_{2}$ (Metz et al., 2005). Transportation costs for $\mathrm{CO}_{2}$ via pipeline or tanker transport varies from 1 to $5 \mathrm{USD} /$ tonne- $\mathrm{CO}_{2} / 250 \mathrm{~km}$ (Metz et al., 2005). Using an average cost of $\$ 3 /$ tonne- $\mathrm{CO}_{2} / 250 \mathrm{~km}$ and an average distance of $500 \mathrm{~km}$ between the $\mathrm{CO}_{2}$ point source and the Electrofuels plant, we predict $\mathrm{CO}_{2}$ transportation costs of $\$ 6 /$ tonne- $\mathrm{CO}_{2}$. Thus, using the total predicted $\mathrm{CO}_{2}$ cost of $\$ 37 /$ tonne- $\mathrm{CO}_{2}$ results in a platform cost of $\$ 17 / \mathrm{bbl}-$ fuel. As shown in Figure $6 \mathrm{~B}$, the overall cost of the Electrofuels production platform (excluding the cost of $\mathrm{H}_{2}$ and the much smaller bioreactor operational requirements for mass transfer) is therefore estimated to be around $\$ 54.3 / \mathrm{bbl}$-fuel, a price well below the target sales price of $\$ 127 / \mathrm{bbl}$-fuel (based on the DOE's estimate of the 2020 price of oil (Gruenspecht, 2012)).

The challenge is therefore to determine the true effect of renewable electricity costs on this technology, which is complicated by the range of various technologies available and the large variability of their costs in North America and around the world. The International Renewable Energy Report (IRENA, 2012) shows that the worldwide LCOE of various renewable energy technologies varies from as low of 4 cents $/ \mathrm{kWh}$ for onshore wind power to a high of $>30$ cents/kWh for large-array solar PV. For North America the averages range from 4 cents/kWh for hydropower to 50 cents/kWh for solar PV (IRENA, 2012; REN21, 2013). The range of final fuel costs, based on the potential range of renewable electricity costs, is shown in Figure 6C. As can be seen, the range of final fuel costs spans a very wide range, which reflects the wide variation 
found in the renewable electricity sources. Furthermore, the lowest projected cost (187.2748.8/bbl-fuel; based on onshore wind electricity) is still about two to six times higher than the 2020 crude oil price estimate (\$127/bbl-fuel) (Gruenspecht, 2012). The highest costs are generally for solar photovoltaics, which are about twenty times that of this baseline crude oil price.

To place the cost of these electricity generation technologies in perspective, we are presenting a brief comparison based on two traditional, fossil fuel based technologies for $\mathrm{H}_{2}$ generation: coal gasification and natural gas reforming. In a recent study, (Bartels et al., 2010) reported hydrogen production costs of $0.36-1.83 \$ / \mathrm{kg}$ and $2.48-3.17 \$ / \mathrm{kg}$ from coal and natural gas respectively. This produces ranges of 68.8-205.4 and 265.8-330 \$/bbl-fuel respectively based on the Electrofuels scenario. Although much lower in cost than some of the renewable technologies for $\mathrm{H}_{2}$ generation, both coal gasification and natural gas reforming generate a much higher ratio of $\mathrm{CO}_{2}$ to $\mathrm{H}_{2}$ than can be consumed by the process. From our analysis, we found that the maximum ratio of consumption of $\mathrm{CO}_{2}$ to $\mathrm{H}_{2}$ in the electrofuels process is $0.2 \mathrm{~mol}-\mathrm{CO}_{2} / \mathrm{mol}-\mathrm{H}_{2}$. On the other hand, the best of coal gasification and natural gas reforming technologies would generate 1.08 and $0.42 \mathrm{~mol}-\mathrm{CO}_{2} / \mathrm{mol}-\mathrm{H}_{2}$. According to these numbers, at least $81 \%$ and $52 \%$ of the $\mathrm{CO}_{2}$ generated by these technologies respectively would be either released to the atmosphere or have to captured by some other process.

It is obvious that at the current crude oil prices and renewable electricity costs, the Electrofuels process is not economically favorable. There are several opportunities that were not taken into account in this analysis that could provide for somewhat improved economics. These include cost reductions for carbon credit, use of low-cost plastic fermentation systems (Hsiao et al., 1999), use of the waste biomass from the process for heating, etc. Furthermore, some of the 
LCOE costs used in the analysis include capital and operating costs for transmission and distribution of the electricity to the grid, which is not necessary if a direct electrolysis process is adopted. Nonetheless, the overall analysis provides quantitative evidence that even with improvements and meeting cellular productivity metrics, the proposed process does not achieve economic feasibility in terms of producing a fuel product. It is not entirely unexpected that an electrofuel would have difficulty competing with crude oil at the current price, as the energy content of crude oil is a result of millions of years of accumulation.

\subsection{Alternative perspective}

A potential advantage of the hypothetical electrofuels process that is not captured in this analysis is the potential for using this microbial platform to make alternative, high-value products by leveraging the high specificity of synthesis that is an inherent capability of biological systems. Through the use of genetic engineering, the autotrophic host could be designed to produce biochemical products with very high degree of specificity. For example, in parallel to the genetic engineering efforts to produce botryococcene, we have also demonstrated squalene production in Rba. capsulatus (unpublished data). The current bulk price of squalene is $\$ 15-20 / \mathrm{kg}$, which translates to about \$2027-2702/bbl-fuel. Other isoprenoids, such as lycopene, valencene, betacarotene, etc., are also high value products whose production are demonstrated in non-native hosts (Alper et al., 2005; Beekwilder et al., 2014; Verwaal et al., 2007). Wax ester (a health product commonly sold as Jojoba oil) is a fatty ester for which we have also demonstrated production in Rba. capsulatus (unpublished data). At $\sim \$ 68 / \mathrm{L}$, the retail price of Jojoba oil translates to a price of $\$ 8064 / \mathrm{bbl}$-fuel. These examples demonstrate the potential value of alternative products able to be generated by a biological production platform using a sustainable, renewable substrate. This alternative paradigm for Electrofuels commercialization could 
facilitate the simultaneous production of multiple high value products (different reactors employing different genetically modified strains) using remote sources of electricity/energy. This could be an alternative use of the electrofuels process during the technology development phase until reductions in the cost of renewable electricity and/or the rise in the price of crude oil make Electrofuels production economically feasible.

\subsection{Targets based on the analysis}

One of the primary goals of this analysis was to first establish the effect of the key process parameters $-Y_{H_{2}}^{T}$ and $m_{H_{2}}$ of the bacteria, $\tau, R_{f u e l}$ and $k_{L} a-$ on the cost of fuel produced by an Electrofuels process, and subsequently define the target productivity metrics for potential feasibility. The range of values for $R_{f u e l}$ and $k_{L} a$ used in this analysis were selected based on realistic engineering considerations of what is actually feasible, while $Y_{H_{2}}^{T}$ and $m_{H_{2}}$ are measured physiological values. The value of the residence time parameter $(\tau)$ is subsequently constrained by these parameters.

It was found that the cost of $\mathrm{H}_{2}$ generation (i.e. the cost of electricity) accounts for $>90 \%$ of the current cost of fuel from the Electrofuels process. The next largest costs are the capital investment required for other non- $\mathrm{H}_{2}$ process equipment and the operating costs for providing mass transfer and supplying $\mathrm{CO}_{2}$. Therefore, steps that decrease $\mathrm{H}_{2}$ consumption would drastically improve process economics. Critical steps include using a host organism with high $Y_{H_{2}}^{T}$ and low $m_{H_{2}}$, and improving the specific fuel productivity to achieve a target $>0.3 \mathrm{~g}$ fuel. $\mathrm{gDW}^{-1} \cdot \mathrm{hr}^{-1}$. The sharpest change in $\mathrm{H}_{2}$ cost occurs at specific productivities below 0.5 , where $\mathrm{H}_{2}$ costs escalate rapidly. This means that incremental changes in productivity in this range have a large impact on the process economics. Also, since the cost of $k_{L} a$ is low relative to 
the $\mathrm{H}_{2}$ generation cost, and because increases in mass transfer have the potential to drastically decrease the required reactor volume (and thus reduce capital cost), it is advantageous to use a bioreactor that can achieve large $k_{L} a$, even at the expense of increased energy costs for achieving a target $k_{L} a$.

The other major goal of this analysis was to assess the overall economic feasibility of an Electrofuels process. It was found that above a specific fuel productivity of 0.3 , the process can be feasible at an LCOE $<2 \varnothing / \mathrm{kWh}$ at the current crude oil prices; this LCOE is about 2-20 times lower than the cost of electricity by current renewable electricity technologies. Given that the economic feasibility is the primary concern, producing fuels via the Electrofuels process is not a viable option at the moment. However, the various technologies considered in this analysis (renewable electricity, autotrophic host, engineering and energetics of hydrocarbon pathways) are in early developmental phase and have the potential to drastically change the economics in future. Alternative higher-value biochemical targets such as lubricants may be pursued during this phase of development to act as economic motivator for near-term profitability, so that the technologies can be developed for application when the rising crude oil prices (due to the depletion of reserves) allow acceptable economics for this process.

\section{Conclusions}

Cost of electricity (for $\mathrm{H}_{2}$ generation) was found to have the largest impact on process economics. Given the assumptions made and current crude oil prices, the process is expected to be feasible at an LCOE $\leq 2 \varnothing / \mathrm{kWh}$. Performance parameters examined in this analysis included both organism-specific physiological parameters, and parameters for process operational modes. A critical requirement for economic feasibility is an autotrophic host with a high yield on 
hydrogen, low metabolic maintenance energy requirements, and able to meet a specific fuel productivity metric of $>0.3 \mathrm{~g}$-fuel. $\mathrm{gDW}^{-1} \cdot \mathrm{hr}^{-1}$. Gas-liquid mass transfer capabilities of the bioreactor were not found to be critical. 


\section{Acknowledgements}

We would like to thank Erik Wolcott for assistance in compiling literature on mass transfer $\left(k_{L} a\right)$ correlations. We also thank Steven W. Singer, Lawrence Berkeley National Lab, for Ralstonia eutropha cultures, and acknowledge the efforts of Robert Nedwick for discussions and instruction in process economics. We acknowledge support of Penn State's Schreyer Honors College for support of J.A.M. which culminated in the generation of honors thesis for this project. J.A.M. also received full time summer research scholarships from Penn State's Department of Chemical Engineering Bio-Endowment Undergraduate Research Fund. A.L.T. received partial support from an NSF Grant (CBET-0828649) and a subsequent NSF Graduate Research Fellowship (Grant No. 0750966); any opinions, findings, and conclusions or recommendations expressed in this material are those of the authors and do not necessarily reflect the views of the National Science Foundation. This work was funded by an ARPA-e grant from the U.S. Department of Energy (ARPA-e Electrofuels, \#DE-AR0000092) to W.R.C. including a collaborative component to Joe Chappell (U. Kentucky). 


\section{References}

1. Alper, H., Miyaoku, K., Stephanopoulos, G., 2005. Construction of lycopeneoverproducing E. coli strains by combining systematic and combinatorial gene knockout targets. Nat. Biotechnol. 23, 612-6.

2. Bartels, J.R., Pate, M.B., Olson, N.K., 2010. An economic survey of hydrogen production from conventional and alternative energy sources. Int. J. Hydrogen Energy 35, 83718384.

3. Beekwilder, J., van Houwelingen, A., Cankar, K., van Dijk, A.D.J., de Jong, R.M., Stoopen, G., Bouwmeester, H., Achkar, J., Sonke, T., Bosch, D., 2014. Valencene synthase from the heartwood of Nootka cypress (Callitropsis nootkatensis) for biotechnological production of valencene. Plant Biotechnol. J. 12, 174-82.

4. De Castro, C., Carpintero, Ó., Frechoso, F., Mediavilla, M., de Miguel, L.J., 2014. A topdown approach to assess physical and ecological limits of biofuels. Energy 64, 506-512.

5. Derenne, S., Largeau, C., Hetényi, M., Brukner-Wein, A., Connan, J., Lugardon, B., 1997. Chemical structure of the organic matter in a Pliocene maar-type shale: Implicated Botryococcus race strains and formation pathways. Geochim. Cosmochim. Acta 61, 18791889.

6. Farmer, W.R., Liao, J.C., 2001. Precursor balancing for metabolic engineering of lycopene production in Escherichia coli. Biotechnol. Prog. 17, 57-61.

7. Gruenspecht, H., 2012. Annual Energy Outlook 2012, Report\#: DOE/EIA-0383. URL http://www.eia.gov/forecasts/aeo/pdf/0383\%282012\%29.pdf.

8. Hammerschlag, R., 2006. Ethanol's Energy Return on Investment: A Survey of the Literature 1990-Present. Environ. Sci. Technol. 40, 1744-1750.

9. Hildebrand, A., Schlacta, T., Warmack, R., Kasuga, T., Fan, Z., 2013. Engineering Escherichia coli for improved ethanol production from gluconate. J. Biotechnol. 168, 1016.

10. Hillen, L.W., Pollard, G., Wake, L. V, White, N., 1982. Hydrocracking of the oils of Botryococcus braunii to transport fuels. Biotechnol. Bioeng. 24, 193-205.

11. Hoekema, S., Douma, R.D.R.D., Janssen, M., Tramper, J., Wijffels, R.H., 2006. Controlling light-use by Rhodobacter capsulatus continuous cultures in a flat-panel photobioreactor. Biotechnol. Bioeng. 95, 613-626.

12. Hsiao, T., Bacani, F., Carvalho, E., Curtis, W.R., 1999. Development of a low capital investment reactor system: application for plant cell suspension culture. Biotechnol. Prog. $15,114-22$. 
13. Hunter, C., Daldal, F., Thurnauer, M.C., Beatty, J.T. (Eds.), 2009. Advances in Photosynthesis and Respiration. Volume 28: The Purple Phototrophic Bacteria. Springer, Dordrecht, The Netherlands. 978-1-4020-8815-5.

14. IRENA, 2012. Renewable Power Generation Costs in 2012 : An Overview. URL http://costing.irena.org/media/2769/Overview_Renewable-Power-Generation-Costs-in2012.pdf.

15. Ishizaki, A., Tanaka, K., 1990. Batch culture of Alcaligenes eutrophus ATCC 17697T using recycled gas closed circuit culture system. J. Ferment. Bioeng. 69, 170-174.

16. Khan, N.E., Myers, J.A., Johnson, R., Rajangam, A., Nybo, E., Chappell, J., Curtis, W., 2013. Progress and Economic Considerations for the Biological Production of Triterpene Biofuels From Gases, in: AICHE 2013 Annual Meeting. Pittsburgh, PA.

17. Khatri, W., Hendrix, R., Niehaus, T., Chappell, J., Curtis, W.R., 2014. Hydrocarbon production in high density Botryococcus braunii race B continuous culture. Biotechnol. Bioeng. 111, 493-503.

18. Kim, S.-W., Kim, J.-B., Jung, W.-H., Kim, J.-H., Jung, J.-K., 2006. Over-production of beta-carotene from metabolically engineered Escherichia coli. Biotechnol. Lett. 28, 897904.

19. Mccarty, P.L., 1971. Engetics and Bacterial Growth, in: Faust, S.J., Hunter, J. V. (Eds.), Organic Compounds in Aquatic Environment. Marcel Dekker, Inc., New York, NY, pp. 495-531.

20. McCarty, P.L., 2007. Thermodynamic electron equivalents model for bacterial yield prediction: Modifications and comparative evaluations. Biotechnol. Bioeng. 97, 377-388.

21. Metz, B., Davidson, O., Coninck, H. de, Loos, M., Meyer, L., 2005. IPCC special report on carbon dioxide capture and storage. Cambridge University Press, New York, NY. ISBN-13 978-0-521-86643-9.

22. Metzger, P., Largeau, C., 2005. Botryococcus braunii: a rich source for hydrocarbons and related ether lipids. Appl. Microbiol. Biotechnol. 66, 486-96.

23. Myers, J., 2013. The scaled-up process design and economic analysis of an electorfuels platform for producing botryococcene as an alternative transportation fuel.

24. Nebraska, 2014. Ethanol Facilities Capacity by State and Plant [WWW Document]. URL http://www.neo.ne.gov/statshtml/122.htm

25. Ohta, K., Beall, D., Mejia, J., Shanmugam, K., Ingram, L., 1991. Genetic improvement of Escherichia coli for ethanol production: chromosomal integration of Zymomonas mobilis 
genes encoding pyruvate decarboxylase and alcohol. Appl. Environ. Microbiol. 57, 893900 .

26. Okada, S., Devarenne, T., Murakami, M., Abe, H., Chappell, J., 2004. Characterization of botryococcene synthase enzyme activity, a squalene synthase-like activity from the green microalga Botryococcus braunii, Race B. Arch. Biochem. 422, 110-118.

27. Pirt, S.J., 1965. The maintenance energy of bacteria in growing cultures. Proc. R. Soc. London. Ser. B, Biol. Sci. 163, 224-231.

28. REN21, 2013. Renewables 2013: Global Status Report. URL http://www.ren21.net/portals/0/documents/resources/gsr/2013/gsr2013_lowres.pdf.

29. Saur, G., 2008. Wind-To-Hydrogen Project: Electrolyzer Capital Cost Study. URL http://www.nrel.gov/docs/fy09osti/44103.pdf.

30. Solomon, B.D., Barnes, J.R., Halvorsen, K.E., 2007. Grain and Cellulosic Ethanol: History, Economics, and Energy Policy. Biomass and Bioenergy 31, 416-425.

31. Steinbrenner, J., Sandmann, G., 2006. Transformation of the green alga Haematococcus pluvialis with a phytoene desaturase for accelerated astaxanthin biosynthesis. Appl. Environ. Microbiol. 72, 7477-84.

32. Tanaka, K., Ishizaki, A., Kanamaru, T., Kawano, T., 1995. Production of poly (D-3hydroxybutyrate) from $\mathrm{CO} 2, \mathrm{H} 2$, and $\mathrm{O} 2$ by high cell density autotrophic cultivation of Alcaligenes eutrophus. Biotechnol. Bioeng. 45, 268-275.

33. Tuerk, A. (Thesis), 2011. An assessment of photosynthetic biofuels and electrofuels technologies under rate-limited conditions. The Pennsylvania State University.

34. Van Bodegom, P., 2007. Microbial maintenance: a critical review on its quantification. Microb. Ecol. 53, 513-23.

35. Verwaal, R., Wang, J., Meijnen, J.-P., Visser, H., Sandmann, G., van den Berg, J. a, van Ooyen, A.J.J., 2007. High-level production of beta-carotene in Saccharomyces cerevisiae by successive transformation with carotenogenic genes from Xanthophyllomyces dendrorhous. Appl. Environ. Microbiol. 73, 4342-50. 
Table 1: Parameter values used in final scaled-up design.

\begin{tabular}{ll}
\hline Parameter & Value \\
\hline Plant size & $5000 \mathrm{bbl} / \mathrm{day}$ \\
Specific productivity & $0.5 \mathrm{gfuel} / \mathrm{gDW} \cdot \mathrm{hr}$ \\
Oxygen mass-transfer coefficient $\left(\mathrm{k}_{\mathrm{L}} \mathrm{a}\right)$ & $1000 / \mathrm{hr}$ \\
Cell recycle & $95 \%$
\end{tabular}



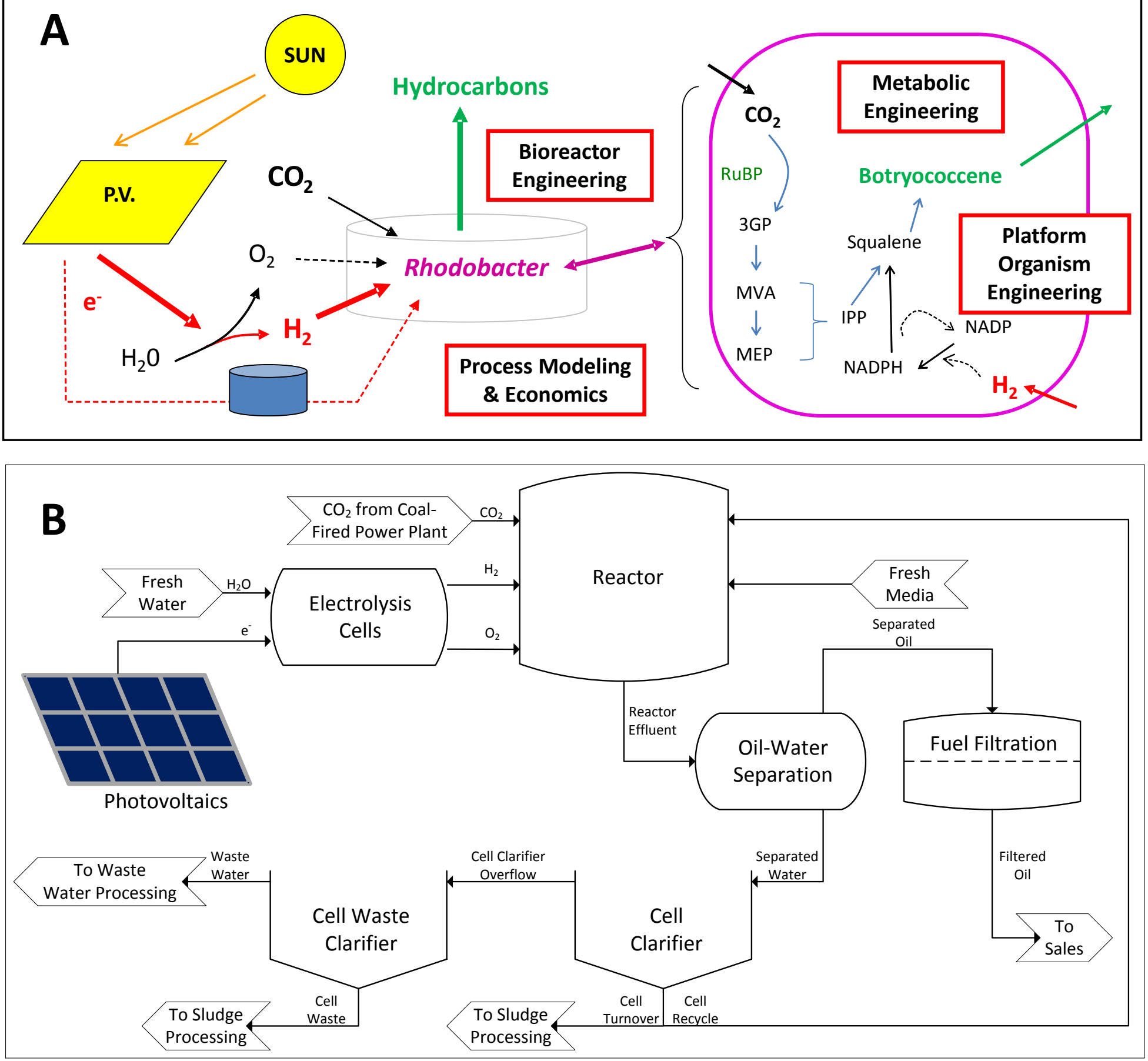

Figure 1: (A) Conceptual depiction of an Electrofuels process. Energy from the sun is captured in the form of renewable electricity (depicted as solar photovoltaics, PV) and is used to split water. The resulting $\mathrm{O}_{2}$ and $\mathrm{H}_{2}$ is combined with $\mathrm{CO}_{2}$ and fed into a bioreactor where Rba. capsulatus consumes these gases in stoichiometric requirement. $R$ ba. capsulatus is genetically engineered to produce a $\mathrm{C}_{30+}$ triterpene hydrocarbon which can be recovered as an extracellular phase-separated oil. (B) Process flow diagram of the envisioned Electrofuels process. 


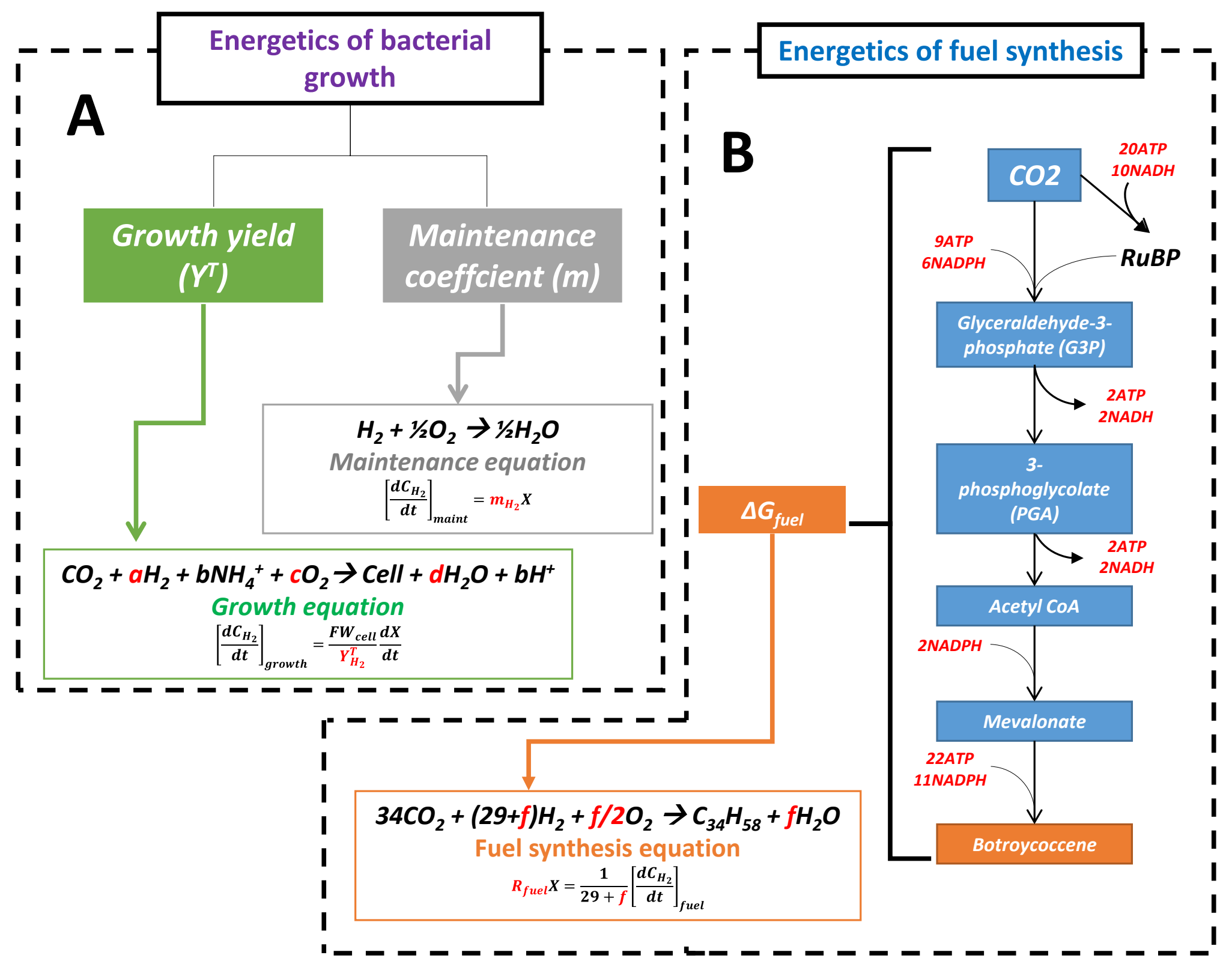

Figure 2: Framework for capturing microbial growth energetics, cellular maintenance and fuel production. (A) Incorporating the experimentally measured biological yield and maintenance coefficients into model reaction/stoichiometry equations suitable for reactor design. (B) Concise version of metabolic pathway for calculating the minimum required Gibbs' free energy for fuel synthesis in a bacteria. 

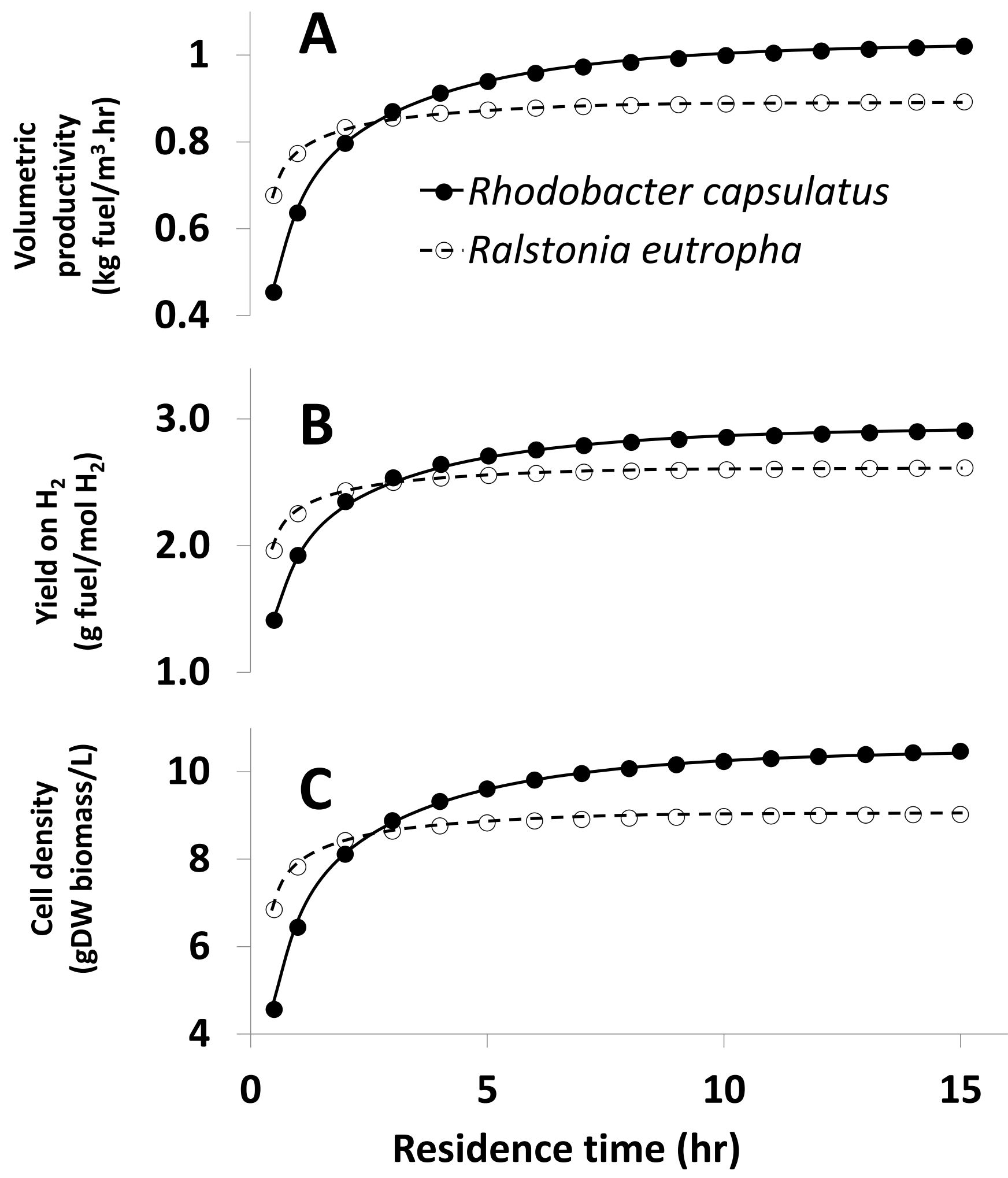

Figure 3: Variation of volumetric productivity, $R_{f u e l}(\mathrm{~A})$, fuel yield on $\mathrm{H}_{2}, Y_{f / H_{2}}(\mathrm{~B})$ and cell density, $X(\mathrm{C})$ as a function of residence time $(\tau)$ through the reactor for Rhodobacter capsulatus $(\bullet)$ and Ralstonia eutropha (o). Simulation parameters: true growth yield $\left(Y_{H_{2}}^{T}\right)$ of $R$. capsulatus $=2.66, R$. eutropha $=7.68 \mathrm{gDW} / \mathrm{mol}-$ $\mathrm{H}_{2}$, maintenance coefficients $\left(m_{\mathrm{H}_{2}}\right)$ of $R$. capsulatus $=2.01 \times 10^{-3}, R$. eutropha $=6.8 \times 10^{-3} \mathrm{~mol}^{-\mathrm{H}_{2}} / \mathrm{gDW} \cdot \mathrm{hr}, \mathrm{k}_{\mathrm{L}} \mathrm{a}$ $=330 / \mathrm{hr}$, specific productivity $=0.5 \mathrm{~g}$ fuel $/ \mathrm{g}$ biomass. $\mathrm{hr}$, cell recycle efficiency $=95 \%$. 


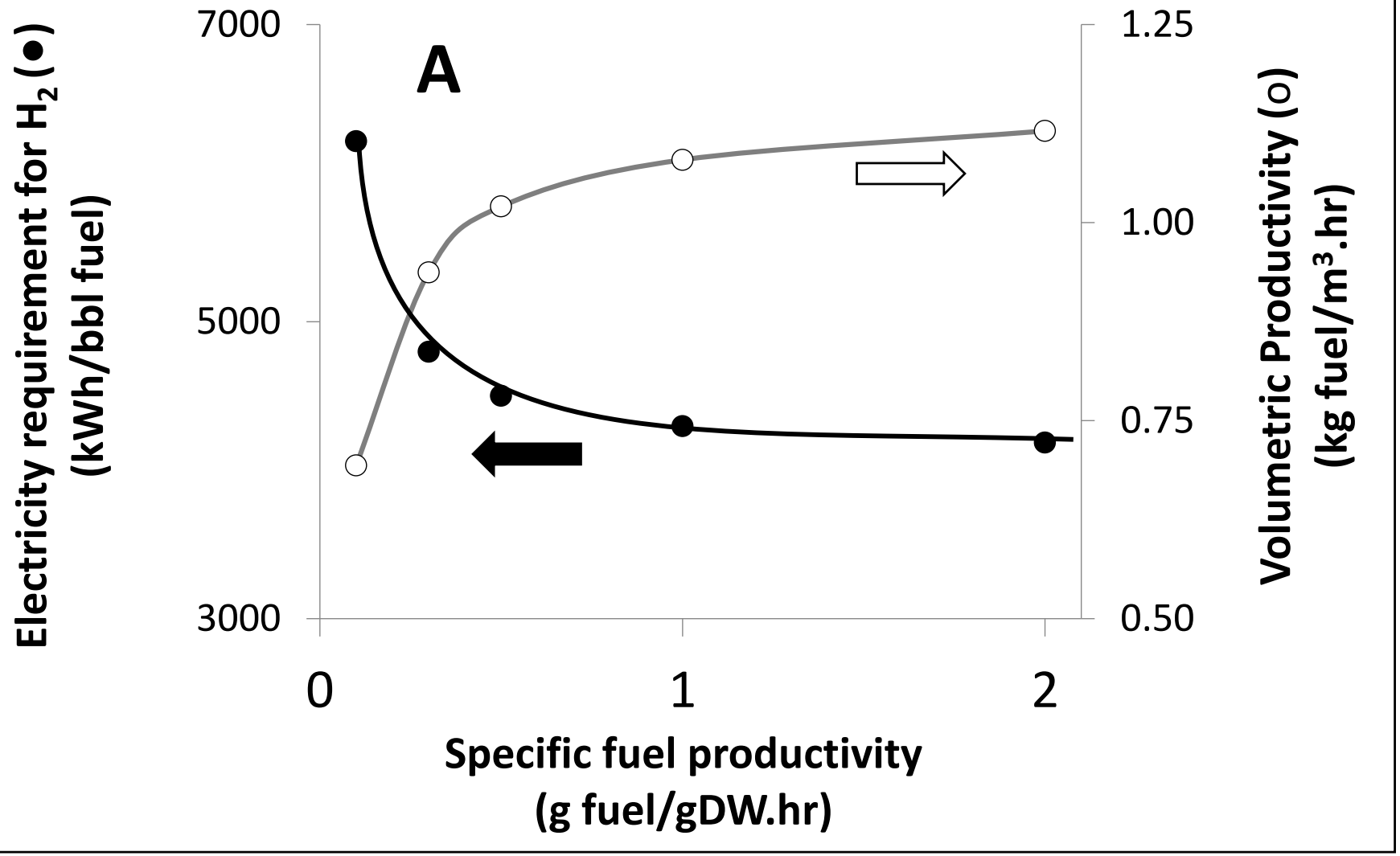

B

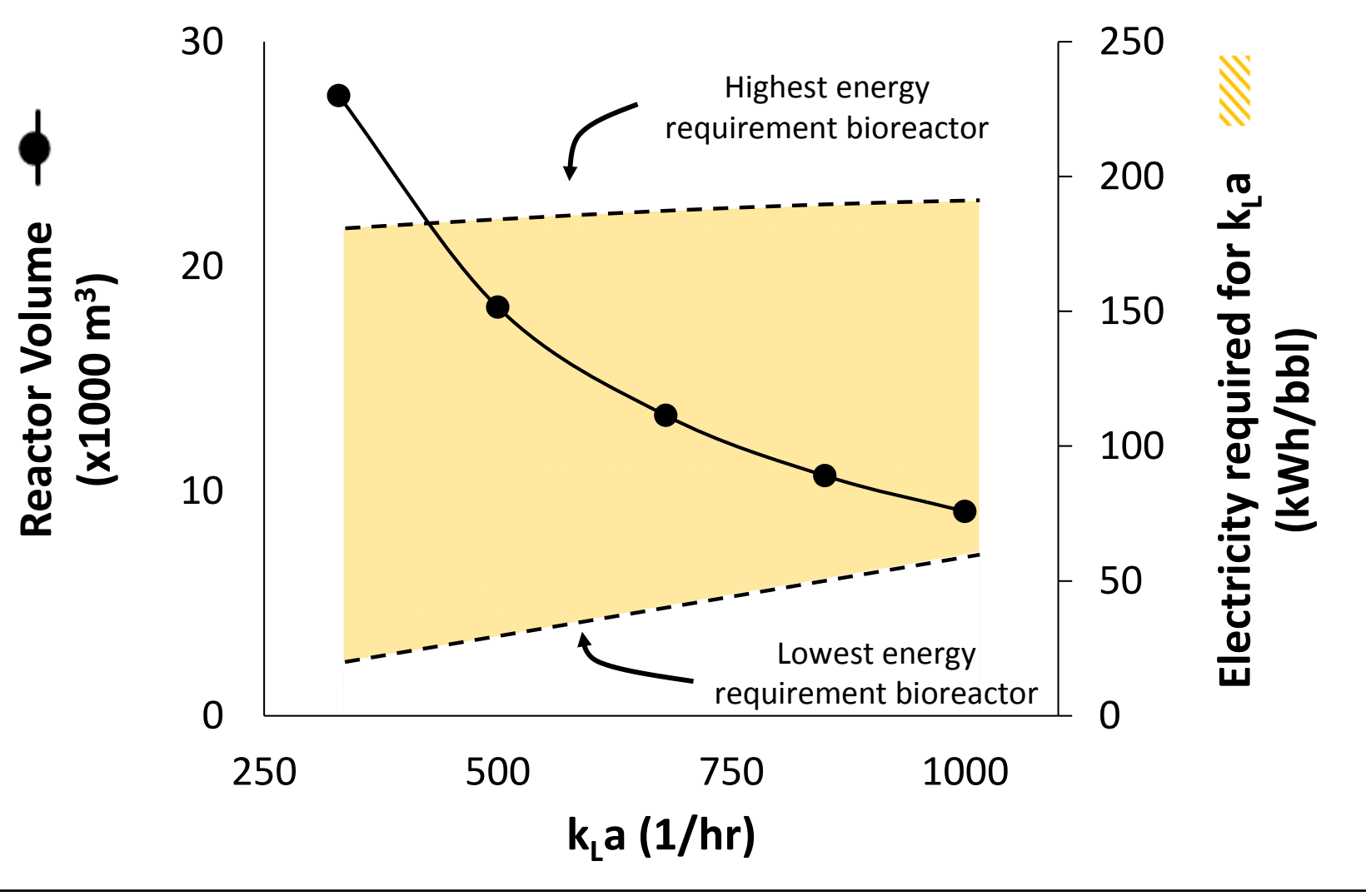

Figure 4: (A) Variation of electricity requirement for $\mathrm{H}_{2}$ generation $(\bullet)$ and volumetric productivity (o) with specific fuel productivity representing an increasing fraction of energy being converted into fuel instead of biomass (Simulation parameters: residence time $=15 \mathrm{hr}$; other parameters same as in Figure 3). (B) Variation in reactor volume as a function of $\mathrm{k}_{\mathrm{L}}$ a showing the reduction in culture process volume that is enabled as the mass transfer rate is improved $(\bullet)$. The range of electricity requirements that would be required to achieve the specified $\mathrm{k}_{\mathrm{L}} \mathrm{a}$ in different bioreactor configuration is shown as the shaded area between the dashed lines. The high and the low value of the electricity requirement at each $\mathrm{k}_{\mathrm{L}}$ a corresponds to the highest and the lowest $\mathrm{P} / \mathrm{V}$ able to produce the specified $\mathrm{k}_{\mathrm{L}} \mathrm{a}$; the range of $\mathrm{P} / \mathrm{V}$ for a variety of bioreactor configurations are presented in Figure 5. 


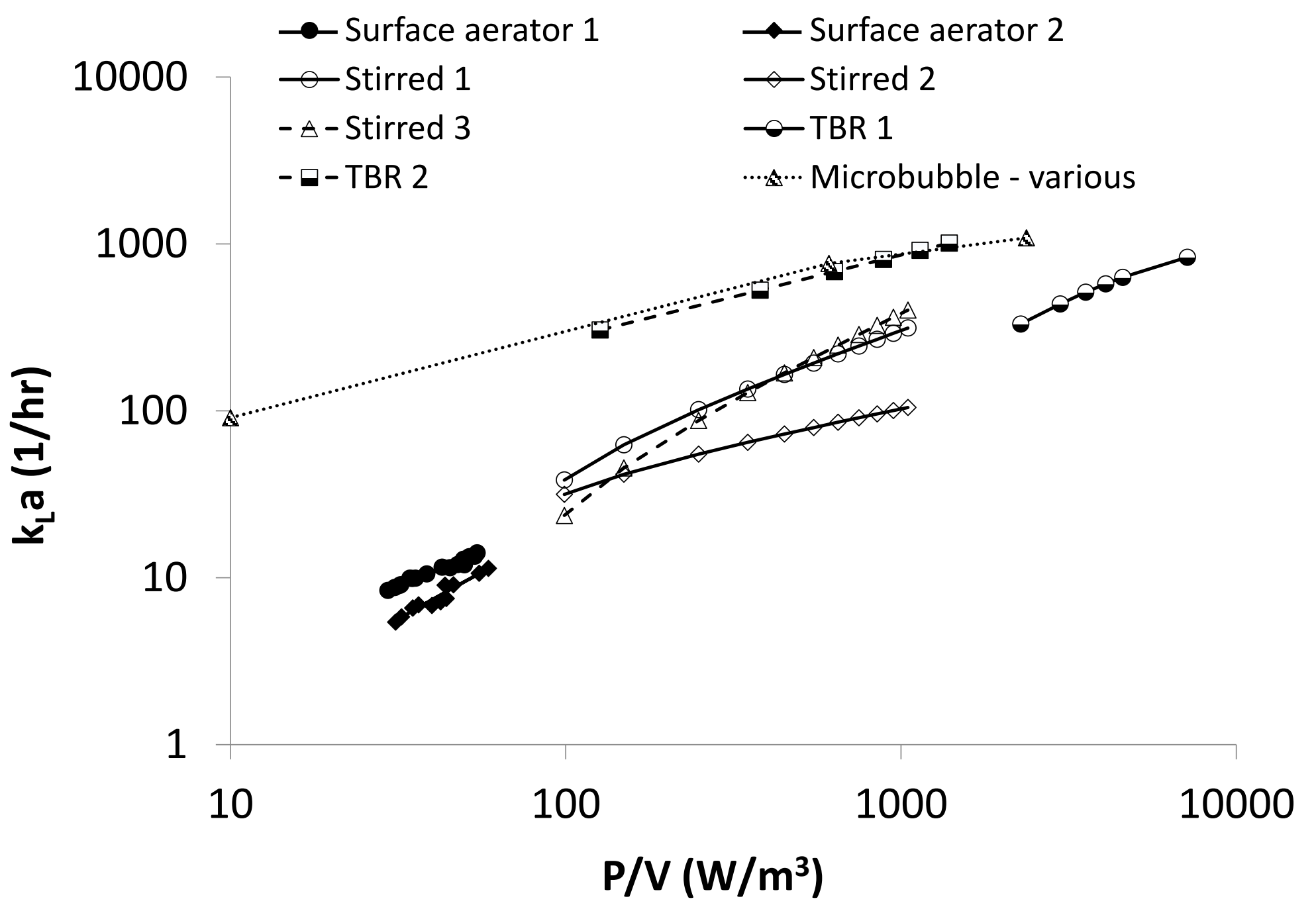

Figure 5: Gas-liquid mass transfer coefficient $\left(\mathrm{k}_{\mathrm{L}} \mathrm{a}\right)$ vs. power/volume (P/V) for various reactor types.

Surface aerator 1 = wastewater treatment plant demonstration run, Chattanooga, TN (Cosby \& Gay, 2003); Surface aerator 2 = wastewater treatment plant demonstration run, Yuba City, CA (Lewis \& Gay, 2003); Stirred $1=$ stirred tank reactors correlation for electrolytes, (Van't Riet, 1979), Vs $=0.005 \mathrm{~m} / \mathrm{s}$; Stirred $2=$ stirred tank reactor correlation for non-electrolytes (Van't Riet, 1979), Vs $=0.005 \mathrm{~m} / \mathrm{s}$; Stirred $3=$ stirred tank reactors correlation for electrolytes (Linek et al., 1987), Vs $=0.005 \mathrm{~m} / \mathrm{s}$; TBR 1 = trickle-bed reactor correlation set 1 (Reactor parameters: Roininen et al., 2009, kLa correlation: Goto \& Smith, 1975, pressure-drop correlation: Larachi et al., 1991); TBR 2 = trickle-bed reactor correlation set 1 (Reactor parameters: Roininen et al., 2009, $\mathrm{k}_{\mathrm{L}}$ a correlation and pressure-drop correlation: Reiss, 1967); Microbubble - various = experimental data from various investigators (Bredwell \& Worden, 1998; Hensirisak et al., 2002). This compilation of literature values focuses on large-scale commercial units (except for microbubble technology). 

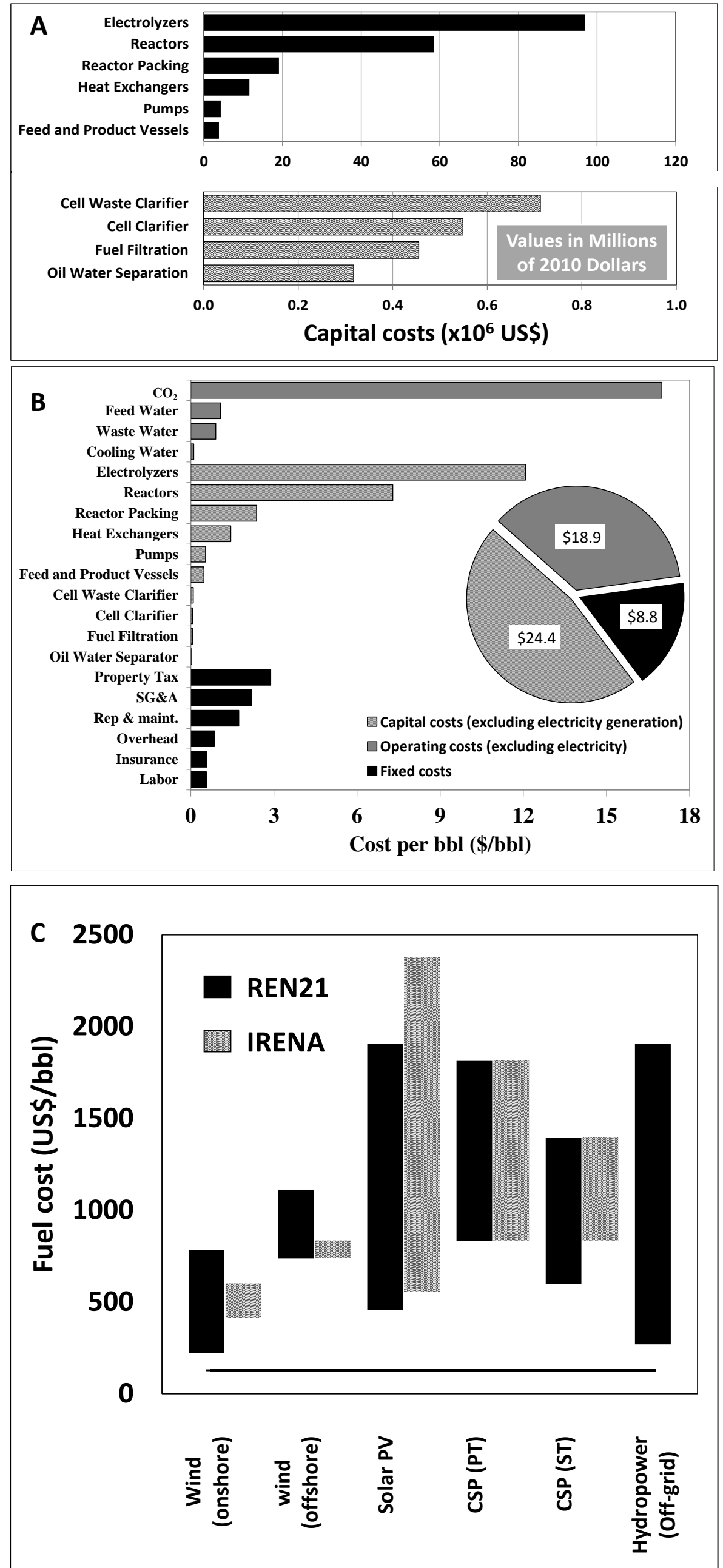

Figure 6: (A) Capital costs of various process components for a 5000 bbl/day fuel production plant. Results are grouped into high (black bards) and low (dashed bars) range capital costs. (B) A breakdown of process costs (the dominant cost of electricity generation is not presented). Top (grey) group represents the major operating costs which make up $36 \%$ of total; middle (hashed) group represents the major non-photovoltaic capital costs which make up $46 \%$ of total; bottom (black) group estimates the major non-PV fixed costs corresponding to $17 \%$ of the total. (C) A sensitivity analysis of the final fuel cost based on LCOE of various generation methods reported in two different sources: REN21, 2013 (black); IRENA, 2012 (dashed). CSP = Concentrate Solar Power, PT = Parabolic Trough, ST = Solar Tower. The horizontal line indicates year 2020 crude oil price estimate (Gruenspecht, 2012). Off-grid hydropower values were not available in IRENA, 2012. 